\title{
sciendo
}

Transport and Telecommunication, 2020, volume 21, no. 3, 221-230

Transport and Telecommunication Institute, Lomonosova 1, Riga, LV-1019, Latvia

DOI 10.2478/ttj-2020-0018

\section{INVESTIGATING THE EFFECTS OF ACTIVE TRAVEL IN HEALTH AND QUALITY OF LIFE}

\author{
Giannis Adamos ${ }^{1}$, Eftihia Nathanail ${ }^{2}$, Parthena Theodoridou ${ }^{3}$, Theodora Tsolaki ${ }^{4}$ \\ University of Thessaly, Department of Civil Engineering \\ Pedion Areos, GR-38334 Volos, Greece \\ 'giadamos@civ.uth.gr \\ 2enath@uth.gr \\ 3nenatheod@gmail.com \\ ${ }^{4}$ th.tsolaki@gmail.com
}

\begin{abstract}
The ever-increasing tendency of people to travel by motorized vehicles contributes significantly to air pollution and traffic problems. Active travel, namely walking and cycling, seems to be a feasible solution to the current situation in urban mobility. The present paper aims at investigating the effects of active travel in health and quality of life and determine those factors that affect travel behavior. A structured literature review was carried out, which revealed the strong association of walking/cycling with the containment of noncommunicable diseases and the invigoration of wellbeing and self-confidence. In addition, a questionnaire survey was conducted in Greece, addressing the attitudes and perceptions of 507 people towards active travel, health and quality of life. Results showed that participants have a more positive attitude about walking compared to cycling, while characteristics such as age, gender, body mass index, physical and health conditions determine active commuting and consequently life satisfaction.
\end{abstract}

Keywords: Sustainability; walking; cycling; physical activity; wellbeing; travel behavior

\section{Introduction}

Traditionally, transportation and urban planning has favoured motorized transport, resulting in significant impacts to environment, economy, society and public health (Tao et al., 2019). Travelers' dependence on private vehicles leads to congestion, severe air pollution and high noise levels especially in city centers. Along with public transport, active travel is recognized as the most important components of sustainable urban mobility (Van Wee \& Handy, 2014).

Active travel can be performed solely by walking or cycling all the way to destination, i.e. work, school/university and shopping centers, or as part of a multimodal trip. In the latter case, people may walk or cycle to a transit stop, transfer and walk to the end location or drive a car for some distance and combine this trip with walking, cycling or public transportation (Pratt et al., 2012). Active travel is strongly associated with the built environment, i.e. neighbourhoods where people live and travel, including also the aspect of accessibility to road and public transport networks (Handy et al., 2002). For example, it is indicated that residents of more walkable traditional or neo-traditional neighbourhoods are more likely to undertake active travel, compared to inhabitants of modern blocks of houses (Handy, 2005). In addition, human interaction with the urban environment, e.g. public spaces, defines the quality of life within cities (Das, 2008). Walking and cycling enable social interactions, through which people exchange their experiences about activity-based mobility choices, formulating in this way social links that require the appropriate networks (Arentze \& Timmermans, 2008).

Strategies and interventions to encourage transition from private vehicles to sustainable means of mobility, like active travel, are initiated by concerns to ameliorate health through the promotion of physical activity (de Nazelle et al., 2011), since physical inactivity is considered to be a significant risk factor for noncommunicable diseases, resulting to 3.2 million deaths per year globally (Lim et al., 2012). Towards this direction, the World Health Organization (WHO) recommends that adults should accumulate at least 30 minutes of moderate activity on most days of the week, i.e. 150 minutes per week, for health benefits to be accomplished (WHO, 2004). Regular moderate to vigorous physical activity seems to reduce the risks of obesity, cardiovascular diseases, diabetes and premature death (Hamer \& Chida, 2008; Laverty et al., 2013; MacDonald, et al., 2010; Wen et al., 2008). Active travel sorely or in combination with public transport meets these standards of physical activity and can be incorporated into daily commuting to work or school and university. It is also important that, unlike sports or intense 
activity, walking and cycling can be easily adopted by almost all people, regardless their age, income or social status (Dons et al., 2015).

Evidence from literature reveals that the achievement of adequate physical activity drives to a lot of health benefits. For example, a study by Bassett et al. (2008) showed that those countries, where a high percentage of trips are performed by walking or cycling tend to have lower rates of obesity. Pucher et al. (2010) studied active travel in relation to physical activity, obesity and diabetes and observed significant health benefits that are associated with active travel behavior. Another study investigated the association of transport mode and body mass index and revealed that people who drive to work are $13 \%$ more likely to be overweigh in relation with those who travel by other modes (Wen et al., 2006). In addition, men cycling to work or using public transport are significantly less likely to be overweight than those who drive (Wen et al., 2008). The latter findings are in accordance with respective outcomes of studies addressing the importance of active commuting by public transportation, which validate that public transportation commuters accumulate significantly more physical activity per week, compared to people who use motorized transport modes (Lachapelle et al., 2010).

Quality and satisfaction of life seem also to be related to daily traveling and more specifically to modal choice. In general, studies show that people who regularly travel to work, independently of the mode they choose, are on average less satisfied with their lives than those who work from home (Office for National Statistics, 2004). Travel time, road infrastructure, travel distance, safety concerns, travel costs and the urban environment are amongst the main factors that influence the degree of life satisfaction of commuters (Hunt \& Abraham, 2007; Steg, 2005). Focusing on active travel, it is indicated that people who adopt walking and cycling in their daily traveling, state that they are more satisfied in their life, compared to those who choose to travel by their private vehicles (Gatersleben \& Uzzell, 2007). Higher satisfaction with active travel is met in men commuters (St-Louis et al., 2014). Walking and cycling are associated with social interactions, which in turn provide life satisfaction and wellbeing (McCarthy \& Habib, 2018). Cycling is also considered by individuals as an opportunity for reflection and relaxation that improves their mood (Friman et al., 2017; Kaplan et al., 2018).

Highlighting the main findings of the literature review, it can be concluded that active travel is strongly related to physical activity and the respective gains in health and quality of life are vital. The aim of this paper is to investigate for the first time the attitudes and perceptions of Greek commuters towards active travel, health and quality of life. Towards this direction, based on the principles of the Theory of Planned Behavior (Ajzen, 1991), a panhellenic questionnaire survey was organized by the Traffic, Transportation and Logistics Laboratory of University of Thessaly in Greece, targeting 507 individuals. Prediction models were developed to associate commuters' behavior towards cycling and walking with characteristics, such as age, gender, body mass index, physical and health conditions.

The rest of the paper is organized as follows: section 2 includes the methodological approach and data analysis, followed by results in section 3. Lastly, section 4 summarizes the main findings of this research and respective conclusions.

\section{Method and data collection}

In order to capture commuters' perceptions about active travel, health and quality of life, Theory of Planned Behavior (TPB) (Ajzen, 1991) was selected as the theoretical model for the construction of the measurement variables and the development of the questionnaire, which was the technique used for data collection. The specific model associates behavior with attitude and intention, addressing also the effect of social norms, when predicting human behavior (Ajzen, 1991). The structure of the questionnaire, additionally to demographics (e.g. age, gender, income), health background and habits (e.g. frequency of physical activity), included the appropriate questions in order to measure specific variables explaining behavior, such as behavioral and control beliefs, behavioral intentions, descriptive norms, risk comprehension, past behavior and self-reported behavior.

Behavioral beliefs provide the linkage between the behavior of interest and the expected outcomes, behavioral intentions indicate how hard people are willing to try to achieve a goal, descriptive norms reflect what is perceived as common or normal, perceived behavioral control is determined as the person's own perception of how easy or difficult it is to perform the behavior and risk comprehension indicates how dangerous a situation may be (Ajzen, 1991; Deutsch \& Gerald, 1955). Past behavior is associated with intention, but the effect, in this case, is indirect and lastly, self-reported behavior is frequently used to understand the mechanisms that affect behavior (Adamos \& Nathanail, 2015).

The core part of the questionnaire was responded using a 5-point scale, ranging from 1 (Strongly disagree/very unlikely/not at all/never) to 5 (Strongly agree/very likely/a lot/always), depending on the topic addressed. Analytically, TPB variables applied in this study are presented in Table 2. 
The questionnaire was developed in the online platform SurveyMonkey (https://www.surveymonkey.com/) and data were collected from February to April 2019. It is noted, that data collection was anonymous and in compliance with the European Union's General Data Protection Regulation (GDPR). The Traffic, Transportation and Logistics Laboratory of University of Thessaly values the privacy of respondents, keeps the collected data safe and protected from unauthorized access and refrains from sharing any personal information with third parties.

Regarding data analysis, hypothesis testing was applied to assess any differences in commuters' attitudes towards walking and cycling. The null hypothesis $\mathrm{H}_{0}$ was that the median difference between the pairs is zero and the alternative hypothesis $\mathrm{H}_{1}$ was that the median difference is not zero. Wilcoxon Signed-Rank Test was performed to assess differences between the samples in characteristics measured on the 5-point scale. A confidence level of $95 \%$ and confidence interval of 5\% were assumed. In order to investigate the inter-relationships between the individual measurement variables and their relationship with the self-reported variables, bivariate correlations were conducted. In addition, for the development of prediction modes, linear regression analyses were used.

\section{Results}

This section gives an overview of the sample profiles, the average rating of the tested variables, the construction of bivariate correlations between these variables and the respective prediction models, explaining respondents' behavior towards walking and cycling in relation to health and quality of life.

\subsection{Sample profiles, habits and trip patterns}

A summary of the profile of the respondents, e.g. gender, age, body mass index, self-assessment of their physical and health conditions and some trip patterns are presented in Table 1 . The final sample size was defined to 507 users, of which $61 \%$ are women and the remaining $39 \%$ men. Regarding age, most of the respondents are between 18-25 years old (44\%) and highly educated (69\%). Focusing on the employment status, it was observed that respondents are mainly employed (52\%) and students (42\%), while $37 \%$ of the participants have monthly net-income over 1,500 EUR. The majority of the respondents $(34 \%)$ stated that they have no physical activity during the week, however $60 \%$ of them characterize their physical condition as good or very good. Similarly, almost $80 \%$ of the sample assess their health as good or very good. The body mass index of most women (69\%) is classified as normal weight, while most of the men respondents $(87 \%)$ are equally separated into normal weight and overweight. Work (49\%) and education $(31 \%)$ are the main trip purposes, while a high proportion of respondents walk to their destinations $(63 \%)$.

Focusing on health condition, 89 persons out of 507 stated that they face at least one health problem, i.e. arterial hypertension $(22 \%)$, heart problems $(5 \%)$, respiratory problems $(18 \%)$, diabetes $(10 \%)$, depression $(32 \%)$, disabilities $(6 \%)$ or other $(21 \%)$. However, it seems that these problems do not prevent commuters from walking or cycling (Figure 1).

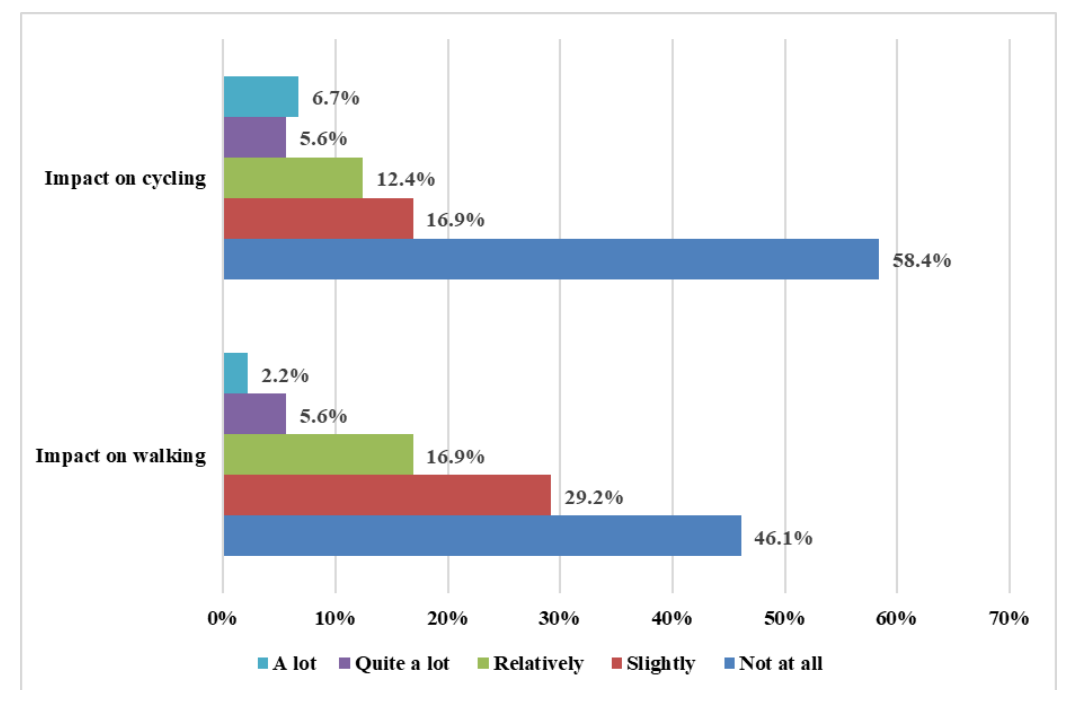

Figure 1. Impact of health problems on walking and cycling 
Table 1. Summary of sample characteristics, habits and trip patterns

\begin{tabular}{|c|c|c|c|c|}
\hline $\begin{array}{l}\text { Characteristic/habits/trip } \\
\text { patterns }\end{array}$ & \multicolumn{2}{|c|}{ Proportion (\%) } & Characteristic/habits/trip patterns & Proportion (\%) \\
\hline \multicolumn{3}{|l|}{ Gender } & \multicolumn{2}{|l|}{ Monthly household income } \\
\hline Male & \multicolumn{2}{|l|}{39} & Low $(<1,000 €)$ & 32 \\
\hline Female & \multicolumn{2}{|l|}{61} & Medium $(1,000-1,500 €)$ & 31 \\
\hline \multicolumn{3}{|l|}{ Age } & $\operatorname{High}(>1,500 €)$ & 37 \\
\hline$<17$ years & \multicolumn{2}{|l|}{0.3} & \multicolumn{2}{|l|}{ Frequency of physical activity } \\
\hline $18-25$ years & \multicolumn{2}{|l|}{44} & Everyday & 9 \\
\hline 26-40 years & \multicolumn{2}{|l|}{24} & At least 3 times a week & 23 \\
\hline $41-65$ years & \multicolumn{2}{|l|}{31} & At least twice a week & 19 \\
\hline$>66$ years & \multicolumn{2}{|l|}{0.7} & Once a week & 15 \\
\hline $\begin{array}{l}\text { Body Mass Index - Weight }(\mathrm{kg}) / \\
\text { Height }(\mathrm{m})^{2}\end{array}$ & Male & Female & Almost never & 34 \\
\hline Underweight & 0 & 4 & \multicolumn{2}{|l|}{ Assessment of physical condition } \\
\hline Normal weight & 44 & 69 & Perfect & 4 \\
\hline Overweight & 43 & 20 & Very good & 22 \\
\hline Obese class I & 10 & 6 & Good & 38 \\
\hline Obese class II & 1.5 & 1 & Average & 29 \\
\hline Obese class III & 1.5 & 0 & Poor & 7 \\
\hline \multicolumn{3}{|l|}{ Educational level } & \multicolumn{2}{|l|}{ Assessment of health } \\
\hline High & \multicolumn{2}{|l|}{69} & Perfect & 11 \\
\hline Secondary & \multicolumn{2}{|l|}{30} & Very good & 42 \\
\hline Primary & \multicolumn{2}{|l|}{1} & Good & 37 \\
\hline \multicolumn{3}{|l|}{ Employment status } & Average & 9 \\
\hline Employed & \multicolumn{2}{|l|}{52} & Poor & 1 \\
\hline Unemployed & \multicolumn{2}{|l|}{5} & \multicolumn{2}{|l|}{ Trip purpose } \\
\hline Student & \multicolumn{2}{|l|}{42} & Work & 49 \\
\hline Other & \multicolumn{2}{|l|}{1} & Education & 31 \\
\hline \multicolumn{3}{|l|}{ Number of people in household } & Shopping & 7 \\
\hline 1 & \multicolumn{2}{|l|}{23} & Leisure & 11 \\
\hline 2 & \multicolumn{2}{|l|}{15} & Other & 2 \\
\hline 3 & \multicolumn{2}{|l|}{18} & Usual transportation mode & \\
\hline 4 & 30 & & Car & 13 \\
\hline$\geq 5$ & 14 & & Motorcycle & 3 \\
\hline Number of vehicles in household & & & Bus & 6 \\
\hline 0 & 23 & & Cycling & 14 \\
\hline 1 & 42 & & Walking & 63 \\
\hline 2 & 30 & & Other & 1 \\
\hline$\geq 3$ & 5 & & & \\
\hline
\end{tabular}

\subsection{Perceptions about active travel}

For the recording of perceptions about active travel, respondents were asked to rate a number of variables, formed according to TPB. The comparative analysis of responses about walking and cycling is presented in Table 2, which shows the average ratings for each variable, as well as the $\mathrm{z}$-statistics, the calculated effect size $(r=z / \sqrt{N}$, where $N$ is the total number of observations $)$ and $p$-value, indicating the strength of the respective evidence.

Findings reveal that respondents in general have a more positive attitude towards walking compared to cycling. For example, they believe that walking is a more pleasant $(\mathrm{r}=-0.3$, $\mathrm{p}$-value $<5 \%$ ) and relaxing $(\mathrm{r}=-0.3, \mathrm{p}$-value $<5 \%)$ activity than cycling. They also believe that walking provides more health benefits $(r=-0.25$, p-value $<5 \%)$ and they consider that walking demands less money $(r=-0.05, p$ value $<5 \%)$ or physical effort $(\mathrm{r}=-0.05, \mathrm{p}$-value $<5 \%)$ than cycling. The latter is characterized more dangerous than walking $(\mathrm{r}=-0.52, \mathrm{p}$-value $<5 \%)$. In addition, participants are willing more to walk in order to improve their health instead of cycling $(\mathrm{r}=-0.41, \mathrm{p}$-value $<5 \%)$, while factors such as weather conditions, time restrictions and their physical condition seem to affect their intention to walk more often in the city. The same trend is met also in participants' family and friendly environment thus, their 
relatives and friends walk more than cycle, in order to improve their health. Lastly, it is clearly observed that walking makes respondents happier and more relaxed and they appreciate the benefits of this activity in their health, along with money savings.

Table 2. Average rating and summary of test results for comparison between walking and cycling

\begin{tabular}{|c|c|c|c|c|c|}
\hline \multirow{2}{*}{ Variables } & \multicolumn{2}{|c|}{ Average rating } & \multirow{2}{*}{ z-statistic } & \multirow{2}{*}{ Effect size (r) } & \multirow{2}{*}{$\frac{\text { p-value }}{\text { W vs. C }}$} \\
\hline & Walking (W) & Cycling (C) & & & \\
\hline \multicolumn{6}{|c|}{ Behavioral beliefs: "I believe that walking/cycling..." } \\
\hline is a pleasant activity & 4.2 & 3.7 & -9.576 & -0.3 & $0^{*}$ \\
\hline is a relaxing activity & 4.0 & 3.4 & -9.752 & -0.3 & $0^{*}$ \\
\hline benefits my health & 4.4 & 4.2 & -7.801 & -0.25 & $0^{*}$ \\
\hline is an economical alternative & 4.5 & 4.4 & -3.523 & -0.11 & $0^{*}$ \\
\hline requires great physical effort & 2.3 & 2.9 & -10.565 & -0.33 & $0^{*}$ \\
\hline \multicolumn{6}{|l|}{ Risk comprehension about: } \\
\hline walking/cycling in the city & 2.1 & 3.5 & -16.689 & -0.52 & $0^{*}$ \\
\hline \multicolumn{6}{|c|}{ Behavioral intentions: "I intend to walk/cycle in the city..." } \\
\hline in order to improve my health & 4.1 & 3.0 & -12.795 & -0.41 & $0^{*}$ \\
\hline \multicolumn{6}{|c|}{ Control beliefs: "I would walk/cycle more often in the city, if..." } \\
\hline the infrastructure was appropriate & 4.1 & 4.2 & -0.952 & -0.03 & 0.341 \\
\hline I had no time restrictions & 4.2 & 3.5 & -11.465 & -0.36 & $0^{*}$ \\
\hline weather conditions were better & 4.1 & 3.9 & -4.327 & -0.14 & $0^{*}$ \\
\hline my physical condition was better & 3.3 & 3.3 & -1.220 & -0.04 & 0.222 \\
\hline my health was better & 3.2 & 3.1 & -2.024 & -0.06 & $0.04 *$ \\
\hline \multicolumn{6}{|c|}{ Descriptive norms: “My relatives and friends...” } \\
\hline $\begin{array}{l}\text { walk/cycle in order to improve their } \\
\text { health }\end{array}$ & 3.1 & 2.3 & -13.098 & -0.41 & $0^{*}$ \\
\hline \multicolumn{6}{|l|}{ Past behavior: } \\
\hline $\begin{array}{l}\text { Frequency of walking/cycling in order } \\
\text { to improve health }\end{array}$ & 3.5 & 1.9 & -15.025 & -0.47 & $0^{*}$ \\
\hline \multicolumn{6}{|c|}{ Self-reported behavior: "I walk/cycle in the city because..." } \\
\hline it makes me happy & 3.9 & 2.4 & -14.478 & -0.45 & $0^{*}$ \\
\hline it relaxes me & 3.7 & 2.3 & -14.337 & -0.45 & $0^{*}$ \\
\hline benefits my heath & 3.7 & 2.3 & -14.129 & -0.44 & $0^{*}$ \\
\hline I save money & 3.5 & 2.3 & -12.916 & -0.41 & $0^{*}$ \\
\hline
\end{tabular}

\subsection{Inter-relationships amongst active travel, health and quality of life}

Table 3 presents the bivariate correlations of the individual variables and their relationship with the variable addressing self-reported behavior towards walking and the degree that this activity improves health. In this case, the dependent variable thus self-reported behavior recorded by respondents' statement "I walk in the city because benefits my health" is correlated with behavioral belief that walking benefits health, risk assessment of walking in the city, control beliefs "I would walk more often in the city if my physical condition was better" and "I would walk more often in the city if my health was better", which are combined into one variable with a value of Cronbach alpha (a) (Cronbach, 1951) equal to 0.824, descriptive norm addressing respondents' perception on actual situations, such as "My relatives and friends walk in order to improve health" and behavior determining the frequency of walking for health improvement in the past. In addition, the dependent variable is correlated with the self-reported physical and health conditions, age, gender, body mass index and health problems.

Results showed that self-reported behavior towards walking and health is more related to behavioral intentions $(\beta=.65, \mathrm{p}$-value $<1 \%)$, past behavior $(\beta=.60$, $\mathrm{p}$-value $<1 \%)$ and behavioral beliefs $(\beta=.51, \mathrm{p}$-value $<1 \%)$. A statistically significant correlation is also indicated with descriptive norms $(\beta=.25, \mathrm{p}$-value $<1 \%)$, physical condition $(\beta=.24$, $\mathrm{p}$-value $<1 \%)$, control beliefs $(\beta=.16$, $\mathrm{p}$-value $<1 \%)$, age $(\beta=.13$, p-value $<1 \%)$ and health condition $(\beta=.11$, p-value $<5 \%)$. On the other hand, a negative relationship is observed between behavior and the variables referring to risk comprehension and body mass index (Table 3). 
Table 3. Bivariate correlations of the individual variables and their relationship with the variable addressing self-reported behavior towards walking and health

\begin{tabular}{|c|c|c|c|c|c|c|c|c|c|c|c|c|c|}
\hline Variables & 1. & 2. & 3. & 4. & 5. & 6. & 7. & 8. & 9. & 10. & 11. & 12. & 13. \\
\hline $\begin{array}{l}\text { 1. Self-reported } \\
\text { behavior }\end{array}$ & - & & & & & & & & & & & & \\
\hline $\begin{array}{l}\text { 2. Behavioral } \\
\text { beliefs }\end{array}$ & $.51 * *$ & - & & & & & & & & & & & \\
\hline $\begin{array}{l}\text { 3. Risk } \\
\text { comprehension }\end{array}$ & $-.18 * *$ & $-.28 * *$ & - & & & & & & & & & & \\
\hline $\begin{array}{l}\text { 4. Behavioral } \\
\text { intentions }\end{array}$ & $.65 * *$ & $.45^{* *}$ & $-.18 * *$ & - & & & & & & & & & \\
\hline $\begin{array}{l}\text { 5. Control } \\
\text { beliefs }\end{array}$ & $.16^{* *}$ & $.14 * *$ & -.06 & $.16^{* *}$ & - & & & & & & & & \\
\hline $\begin{array}{l}\text { 6. Descriptive } \\
\text { norms }\end{array}$ & $.25 * *$ & $.11 *$ & $-.1 *$ & $.16^{* *}$ & .07 & - & & & & & & & \\
\hline 7. Past behavior & $.60 * *$ & $.37 * *$ & $-.09 *$ & $.53 * *$ & $.12 * *$ & $.27 * *$ & - & & & & & & \\
\hline $\begin{array}{l}\text { 8. Physical } \\
\text { condition }\end{array}$ & $.24 * *$ & $.16^{* *}$ & $-.09 *$ & $.17 * *$ & $-.14 * *$ & $.09 *$ & $.20 * *$ & - & & & & & \\
\hline $\begin{array}{l}\text { 9. Health } \\
\text { condition }\end{array}$ & $.11^{*}$ & $.11 *$ & $-.10 *$ & $.09^{*}$ & $-.16 * *$ & .04 & $.12 * *$ & $.59 * *$ & - & & & & \\
\hline 10. Age & $.13 * *$ & .01 & $-.14 * *$ & $.12 * *$ & -.05 & .07 & -.06 & $.14 * *$ & -.02 & - & & & \\
\hline 11. Gender & .07 & .04 & .08 & .07 & .04 & .07 & $.16^{* *}$ & -.05 & .02 & $-.15 * *$ & - & & \\
\hline $\begin{array}{l}\text { 12. Body Mass } \\
\text { Index }\end{array}$ & -.02 & -.02 & .05 & -.02 & $.17 * *$ & .01 & $-.12 * *$ & $-.29 * *$ & $-.25 * *$ & $.25^{* *}$ & $-.9 * *$ & - & \\
\hline $\begin{array}{l}\text { 13. Health } \\
\text { problems }\end{array}$ & .02 & .01 & -.07 & -.01 & $-.09 *$ & -.01 & .04 & $.20 * *$ & $.32 * *$ & -.04 & .04 & $-.2 * *$ & - \\
\hline
\end{tabular}

Table 4 presents the bivariate correlations of the individual variables and their relationship with the variable addressing self-reported behavior towards walking and the degree that this activity improves quality of life. In this case, self-reported behavior recorded by respondents' statements "I walk in the city because it makes me happy", "I walk in the city because it relaxes me" and "I walk in the city because I save money", combined into one variable $(\mathrm{a}=0.772)$, is correlated with behavioral beliefs "Walking is a pleasant activity", "Walking is a relaxing activity" and "Walking is an economical alternative", combined into one variable $(\mathrm{a}=0.747)$ and control beliefs "I would walk more often it the city if the infrastructure was appropriate" and "I would walk more in the city if I had no time restrictions", combined also into one variable $(\mathrm{a}=0.6)$. In addition, the dependent variable is also correlated with risk comprehension, the selfreported physical and health conditions, age, gender, body mass index and health problems. Based on the outcomes of Table 4, it is observed that self-reported behavior towards walking and quality of life is strongly related to behavioral beliefs $(\beta=.67$, $\mathrm{p}$-value $<1 \%)$, physical condition $(\beta=.24$, $\mathrm{p}$-value $<1 \%)$ and control beliefs $(\beta=.22$, p-value $<1 \%)$.

Table 4. Bivariate correlations of the individual variables and their relationship with the variable addressing self-reported behavior towards walking and quality of life

\begin{tabular}{|c|c|c|c|c|c|c|c|c|c|c|}
\hline Variables & 1. & 2. & 3. & 4. & 5. & 6. & 7. & 8. & 9. & 10. \\
\hline $\begin{array}{l}\text { 1. Self-reported } \\
\text { behavior }\end{array}$ & - & & & & & & & & & \\
\hline 2. Behavioral beliefs & $.67 * *$ & - & & & & & & & & \\
\hline $\begin{array}{l}\text { 3. Risk } \\
\text { comprehension }\end{array}$ & $-.09 *$ & $-.26 * *$ & - & & & & & & & \\
\hline 4. Control beliefs & $.22 * *$ & $.24 * *$ & .01 & - & & & & & & \\
\hline 5. Physical condition & $.24 * *$ & $.29 * *$ & $-.09 *$ & .02 & - & & & & & \\
\hline 6. Health condition & $.14 * *$ & $.21 * *$ & $-.10 *$ & .01 & $.59 * *$ & - & & & & \\
\hline 7. Age & -.03 & .06 & $-.14 * *$ & .02 & $.14 * *$ & -.02 & - & & & \\
\hline 8. Gender & $.11 *$ & -.02 & .08 & .07 & -.01 & .02 & $-.15 * *$ & - & & \\
\hline 9. Body Mass Index & -.09 & $-.09 *$ & .05 & .05 & $-.29 * *$ & $-.25 * *$ & $.26 * *$ & $-.28 * *$ & - & \\
\hline 10. Health problems & .07 & $.10 *$ & -.07 & -.01 & $.20 * *$ & $.32 * *$ & -.04 & .04 & $-.22 * *$ & - \\
\hline
\end{tabular}

Table 5 and Table 6 are showing the bivariate correlations of the individual variables and their relationships with the variables addressing self-reported behavior towards cycling and health, and cycling and quality of life, respectively. The construction of the individual and combined variables follows the previous assumptions, adjusted to cycling. It is noted that in all cases, Cronbach alpha is higher than the threshold of 0.6 . 
According to Table 5, it is observed that self-reported behavior towards cycling and health is more related to past behavior $(\beta=.76, \mathrm{p}$-value $<1 \%)$, behavioral intentions $(\beta=.67$, $\mathrm{p}$-value $<1 \%)$ and behavioral beliefs $(\beta=.28, \mathrm{p}$-value $<1 \%)$. A statistically significant correlation is also indicated with descriptive norms $(\beta=.29$, p-value $<1 \%)$, physical condition $(\beta=.19$, p-value $<1 \%)$, control beliefs $(\beta=.13$, $\mathrm{p}$-value $<1 \%)$ and health condition $(\beta=.09, \mathrm{p}$-value $<5 \%)$. On the other hand, a negative relationship is observed between behavior and the variables regarding risk comprehension, age, gender and body mass index.

Table 6 shows that self-reported behavior towards cycling and quality of life is strongly related to behavioral beliefs $(\beta=.48$, p-value $<1 \%)$, control beliefs $(\beta=.27$, p-value $<1 \%)$ and physical condition $(\beta=.21, \mathrm{p}$-value $<1 \%)$.

Table 5. Bivariate correlations of the individual variables and their relationship with the variable addressing self-reported behavior towards cycling and health

\begin{tabular}{|c|c|c|c|c|c|c|c|c|c|c|c|c|c|}
\hline Variables & 1. & 2. & 3. & 4. & 5. & 6. & 7. & 8. & 9. & 10. & 11. & 12. & 13. \\
\hline $\begin{array}{l}\text { 1. Self-reported } \\
\text { behavior }\end{array}$ & - & & & & & & & & & & & & \\
\hline $\begin{array}{l}\text { 2. Behavioral } \\
\text { beliefs }\end{array}$ & $.28 * *$ & - & & & & & & & & & & & \\
\hline $\begin{array}{l}\text { 3. } \text { Risk } \\
\text { comprehension }\end{array}$ & $-.23 * *$ & $.19 * *$ & - & & & & & & & & & & \\
\hline $\begin{array}{l}\text { 4. Behavioral } \\
\text { intentions }\end{array}$ & $.67 * *$ & $.29 * *$ & $.25^{* *}$ & - & & & & & & & & & \\
\hline $\begin{array}{l}\text { 5. Control } \\
\text { beliefs }\end{array}$ & $.13 * *$ & $.12 * *$ & 0 & $.22 * *$ & - & & & & & & & & \\
\hline $\begin{array}{l}\text { 6. Descriptive } \\
\text { norms }\end{array}$ & $.29 * *$ & $.11^{*}$ & $-.16 * *$ & $.21 * *$ & 0 & - & & & & & & & \\
\hline $\begin{array}{l}\text { 7. Past } \\
\text { behavior }\end{array}$ & $.76^{* *}$ & $.23 * *$ & $-.24 * *$ & $.59 * *$ & .06 & $.26^{* *}$ & - & & & & & & \\
\hline $\begin{array}{l}\text { 8. Physical } \\
\text { condition }\end{array}$ & $.19^{* *}$ & $.16 * *$ & -.09 & $.20 * *$ & $-.11 *$ & $.09 *$ & $.23 * *$ & - & & & & & \\
\hline $\begin{array}{l}\text { 9. Health } \\
\text { condition }\end{array}$ & $.09 *$ & $.17 * *$ & -.03 & $.09 *$ & $-.10 *$ & .02 & $.13 * *$ & $.59 * *$ & - & & & & \\
\hline 10. Age & -.01 & -.06 & 0 & 0 & $-.11 *$ & $.18^{* *}$ & .01 & $.14 * *$ & -.02 & - & & & \\
\hline 11. Gender & -.05 & 0 & .05 & 0 & $.14 * *$ & .05 & $-.10^{*}$ & -.05 & .02 & $-.15 * *$ & - & & \\
\hline $\begin{array}{l}\text { 12. Body Mass } \\
\text { Index }\end{array}$ & -.02 & $-.09 *$ & .03 & .03 & .05 & -.03 & -.03 & $-.29 * *$ & $-.25 * *$ & $.26^{* *}$ & $-.28 * *$ & - & \\
\hline $\begin{array}{l}\text { 13. Health } \\
\text { problems }\end{array}$ & .05 & $.10^{*}$ & -.04 & -.07 & .02 & .02 & .08 & $.20 * *$ & $.32 * *$ & -.04 & .04 & $-.2 * *$ & - \\
\hline
\end{tabular}

Table 6. Bivariate correlations of the individual variables and their relationship with the variable addressing self-reported behavior towards cycling and quality of life

\begin{tabular}{|c|c|c|c|c|c|c|c|c|c|c|}
\hline Variables & 1. & 2. & 3. & 4. & 5. & 6. & 7. & 8. & 9. & 10. \\
\hline $\begin{array}{l}\text { 1. Self-reported } \\
\text { behavior }\end{array}$ & - & & & & & & & & & \\
\hline 2. Behavioral beliefs & $.48^{* *}$ & - & & & & & & & & \\
\hline $\begin{array}{l}\text { 3. Risk } \\
\text { comprehension }\end{array}$ & $-.20 * *$ & $-.35^{* *}$ & - & & & & & & & \\
\hline 4. Control beliefs & $.27 * *$ & $.25 * *$ & .06 & - & & & & & & \\
\hline 5. Physical condition & $.21 * *$ & $.24 * *$ & -.09 & $.10^{*}$ & - & & & & & \\
\hline 6. Health condition & $.12 *$ & $.19^{* *}$ & -.03 & $.13 * *$ & $.59 * *$ & - & & & & \\
\hline 7. Age & -.03 & 0 & 0 & 0 & $.14 * *$ & -.02 & - & & & \\
\hline 8. Gender & -.09 & 0 & .05 & .06 & 0 & .02 & $.15^{* *}$ & - & & \\
\hline 9. Body Mass Index & -.03 & -.06 & .03 & 0 & $-.29 * *$ & $-.25 * *$ & $.26^{* *}$ & $-.28 * *$ & - & \\
\hline 10. Health problems & .05 & $.13^{* *}$ & -.04 & .07 & $.20 * *$ & $.32 * *$ & -.04 & .04 & $-.22 * *$ & - \\
\hline
\end{tabular}

Based on the findings of the previous findings and considering the necessary statistical requirements and assumptions (i.e. homoscedasticity, multicollinearity, etc.), prediction models were developed, associating self-reported behavior (dependent variable) with specific variables (independent variables). Table 7 summarizes the models predicting commuters' adoption of walking and cycling for the improvement of health and Table 8 shows the respective models referring to the improvement of quality of life. It is noted that several alternative combinations of variables were tested and those explaining better commuters' behavior, i.e. significant contribution of variables in the prediction thus, higher values of adjusted $\mathrm{R}^{2}$, are analyzed in the following paragraphs. 
Focusing on the prediction of commuters' adoption of walking for the improvement of health, the regression is significant $(\mathrm{F}(8,506)=81.554$, p-value $<0.05)$ and explains $56 \%$ of variance. Based on the values of the indicator Beta (Table 7), "behavioral intentions", "past behavior" and "behavioral beliefs", seem to be the strongest predictors of adopting walking, contributing significantly to the total variances ( $\mathrm{p}$-value $<0.05)$. The weakest variable is "risk comprehension" $(\beta=-.014)$ and this contribution is not statistically significant ( $\mathrm{p}$-value $>0.05$ ). As far as cycling is concerned, it is indicated that "past behavior" $(\beta=0.505)$ and "behavioral beliefs $(\beta=0.330)$ are the strongest predictors. The regression in this case is also significant $(F(8,506)=111.29$, p-value $<0.05)$ and explains $64 \%$ of the variance.

Table 7. Models predicting commuters' adoption of walking and cycling for the improvement of health

\begin{tabular}{|c|c|c|c|c|c|c|c|c|c|c|}
\hline \multirow[b]{2}{*}{ Variables } & \multicolumn{5}{|c|}{ Walking } & \multicolumn{5}{|c|}{ Cycling } \\
\hline & B & $\begin{array}{l}\text { Std. } \\
\text { Error }\end{array}$ & Beta & $\mathbf{t}$ & Sig. & B & $\begin{array}{l}\text { Std. } \\
\text { Error }\end{array}$ & Beta & $\mathbf{t}$ & Sig. \\
\hline Behavioral beliefs & 0.353 & 0.055 & 0.223 & 6.436 & $0 *$ & 0.127 & 0.051 & 0.071 & 2.468 & $0.014 *$ \\
\hline $\begin{array}{l}\text { Risk } \\
\text { comprehension }\end{array}$ & -0.014 & 0.037 & -0.12 & -0.393 & 0.694 & -0.004 & 0.037 & -0.003 & -0.111 & 0.912 \\
\hline $\begin{array}{l}\text { Behavioral } \\
\text { intentions }\end{array}$ & 0.347 & 0.042 & 0.304 & 8.200 & $0 *$ & 0.344 & 0.036 & 0.330 & 9.508 & $0^{*}$ \\
\hline Control beliefs & 0.032 & 0.037 & 0.027 & 0.882 & 0.378 & 0.037 & 0.039 & 0.026 & 0.935 & 0.350 \\
\hline Descriptive norms & 0.100 & 0.040 & 0.077 & 2.486 & $0.013 *$ & 0.111 & 0.039 & 0.079 & 2.821 & $0.005^{*}$ \\
\hline Past behavior & 0.324 & 0.034 & 0.300 & 9.541 & $0^{*}$ & 0.582 & 0.039 & 0.505 & 14.988 & $0^{*}$ \\
\hline Health condition & 0.051 & 0.044 & 0.035 & 1.154 & 0.249 & -0.051 & 0.060 & -0.029 & -0.847 & 0.342 \\
\hline Physical condition & & & & & & 0.049 & 0.052 & 0.033 & 0.950 & 0.398 \\
\hline Age & 0.125 & 0.042 & 0.091 & 2.986 & $0.003^{*}$ & & & & & \\
\hline \multirow[t]{2}{*}{ Constant } & -1.247 & 0.343 & & -3.638 & $0^{*}$ & -0.689 & 0.328 & & -2.098 & $0.036^{*}$ \\
\hline & \multicolumn{5}{|c|}{ Adjusted $R^{2}=.56, F(8,506)=81.554, * p$-value $<5 \%$} & \multicolumn{5}{|c|}{ Adjusted $R^{2}=.64, F(8,506)=111.29, * p$-value $<5 \%$} \\
\hline
\end{tabular}

In the case of predicting commuters' adoption of walking for the improvement of quality of life, the regression is significant $(\mathrm{F}(5,506)=89.484$, p-value $<0.05)$ and explains $47 \%$ of variance. Based on the values of the indicator Beta (Table 8), "behavioral beliefs" $(\beta=.663)$ is the strongest predictor ( $\mathrm{p}$-value $<5 \%$ ). Regarding cycling, similar results are indicated, showing that "behavioral beliefs" $(\beta=.406)$ is the strongest predictor $(\mathrm{p}$-value $<5 \%)$. In addition, positive and statistically significant is the contribution of control beliefs and physical condition. The regression is significant $(\mathrm{F}(8,506)=36.552$, p-value $<0.05)$ and explains $26 \%$ of the variance.

Table 8. Models predicting commuters' adoption of walking and cycling for the improvement of quality of life

\begin{tabular}{|c|c|c|c|c|c|c|c|c|c|c|}
\hline \multirow[b]{2}{*}{ Variables } & \multicolumn{5}{|c|}{ Walking } & \multicolumn{5}{|c|}{ Cycling } \\
\hline & B & $\begin{array}{l}\text { Std. } \\
\text { Error }\end{array}$ & Beta & $\mathbf{t}$ & Sig. & B & $\begin{array}{l}\text { Std. } \\
\text { Error }\end{array}$ & Beta & $\mathbf{t}$ & Sig. \\
\hline Behavioral beliefs & 0.941 & 0.050 & 0.663 & 18.676 & $0 *$ & 0.747 & 0.080 & 0.406 & 9.314 & $0^{*}$ \\
\hline $\begin{array}{l}\text { Risk } \\
\text { comprehension }\end{array}$ & 0.063 & 0.033 & 0.065 & 1.933 & 0.054 & -0.090 & 0.052 & -0.071 & -1.721 & 0.086 \\
\hline Control beliefs & 0.059 & 0.040 & 0.049 & 1.463 & 0.144 & 0.184 & 0.056 & 0.132 & 3.260 & $0.001 *$ \\
\hline Physical condition & 0.056 & 0.034 & 0.056 & 4.653 & 0.099 & 0.187 & 0.072 & 0.126 & 2.589 & $0.01 *$ \\
\hline Health condition & & & & & & -0.083 & 0.085 & -0.047 & -.0976 & 0.329 \\
\hline Gender & 0.206 & 0.065 & 0.103 & 3.157 & $0.002 *$ & & & & & \\
\hline \multirow[t]{2}{*}{ Constant } & -1.160 & 0.280 & & -4.139 & $0 *$ & -1.81 & 0.437 & & -2.702 & $0.007 *$ \\
\hline & \multicolumn{5}{|c|}{ Adjusted $R^{2}=.47, F(5,506)=89.484$, * $p$-value $<5 \%$} & \multicolumn{5}{|c|}{ Adjusted $R^{2}=.26, F(5,506)=36.522, * p-v a l u e<5 \%$} \\
\hline
\end{tabular}

\section{Conclusions}

Acknowledging the main findings of literature that walking and cycling are strongly related to physical activity and that the respective benefits in health and life satisfaction are significant, the aim of this paper was to capture Greek commuters' attitudes and perceptions towards active travel, health and quality of life.

A general outcome of this research is that persons seem to have a more positive attitude about walking compared to cycling and this can be explained by the lack of appropriate infrastructure in most of the cities in Greece and by the fact that commuters consider cycling much more dangerous than walking. Respondents also believe that cycling requires more physical effort than walking, however their physical condition would not affect their choice. In addition, participants relate significantly walking with health and quality of life, since they clearly stated that they walk in the city because this activity makes them happy, relaxes them and offers a lot of benefits to their health. 
When investigating the contribution of several variables to explain commuters' adoption of walking and cycling for the improvement of their health, findings are in line with previous studies (as in Adamos and Nathanail, 2015; Armitage and Conner, 2006; Nathanail and Adamos, 2013), which validate that behavioral intentions and behavioral beliefs are the parameters that mostly affects persons' behavior. Regarding persons' adoption of active travel for the improvement of quality of life, behavioral beliefs are the strongest predictor, while gender affects significantly behavior towards walking, but not cycling. Gender was not indicated as a strong predictor in any of the cases tested.

Concluding, apart from persons' willingness to decrease the use of motorized vehicles and move to active travel, there is evidence that when a city provides new sustainable infrastructure, the promotion of this alternative means of commuting, can be effective (Panter et al., 2016). Social media provide also a significant channel of promoting interventions that can improve public health through active travel (Hong et al., 2018).

Lastly, it is important to provide active accessibility to individuals, meaning the ability to reach relevant activities or services by active travel alone. Special concern should be paid to the needs of older people, children and disabled people, but also to the provision of the appropriate infrastructure for cycling and walking (Vale et al., 2016), i.e. facilities should be reachable within walkable distance (Barton et al., 2012).

\section{References}

1. Adamos, G. \& Nathanail, E. (2015) How to train safe drivers: Setting up and evaluating a fatigue training program. Transport and Telecommunication Journal, 16 (1), 9-20.

2. Ajzen, I. (1991) The theory of planned behavior. Organizational Behavior and Human Decision Processes, 50, 179-211.

3. Armitage, C.J. \& Conner, M. (2006) Efficacy of the theory of planned behavior: A meta-analytic review. British Journal of Social Psychology, 40, 471-499.

4. Arentze, T. \& Timmermans, H. (2008) Social networks, social interactions and activity-travel behavior: A framework for microsimulation. Environment and Planning B: Planning and Design, 35(6), 1012-1027.

5. Barton, H., Horswell, M. \& Millar, P. (2012) Neighbourhood accessibility and active travel. Planning Practice and Research, 27 (2), 177-201.

6. Bassett Dr., Pucher, J., Buehler, R., Thompson, Dl. \& Crouter, SE. (2008) Walking, cycling and obesity rates in Europe, North America and Australia. J Phys Act Health, 5(6), 795-814.

7. Cronbach, L.J. (1951) Coefficient alpha and the internal structure of tests. Psychometrical, 16 (3), 297-334.

8. Das, D. (2008) Urban quality of life: A case study of Guwahati, Springer Science and Business Media B.V., Soc Indic Res., 88, 297-310.

9. De Nazelle, A., Nieuwenhuijsen, N.J., Anto, J.M., et al. (2011) Improving health through policies that promote active travel: a review of evidence to support integrated health impact assessment. Environ. Int., 37, 366-377.

10. Deutsch M \& Gerard H B., (1955) A study of normative and informational social influences upon individual judgment. J. Abnorm. Soc. Psychol, 51, 629-36. Research Center for Human Relations, New York University, New York, NY.

11. Dons, E., Gotschi, Th., Nieuwenhuijsen, M. et al. (2015) Physical activity through Sustainable Transport Approaches (PASTA): protocol foe a multi-centre, longitudinal study. BMC Public Health, $15,1126$.

12. Friman, M., Garling, T., Ettema, D. \& Olsson, L. (2017) How does travel affect emotional well-being and life satisfaction? Transportation Research Part A, 106, 170-180.

13. Gatersleben, B. \& Uzzell, D. (2007) Affective appraisals of the daily commute comparing perceptions of drivers, cyclists, walkers and users of public transport. Environ. Behav, 39, 416-431.

14. Hamer, M. \& Chida, Y. (2008) Active commuting and cardiovascular risk: A meta-analytic review. Prev. Med., 46, 9-13.

15. Handy, S.L., Boarnet, M.G., Ewing, R. \& Killingsworth, R.E. (2002). How the built environment affects physical activity: Views from urban planning. American Journal of Preventive Medicine, 23, 64-73.

16. Handy, S. (2005) Planning for accessibility: In theory and in practice. In Access to Destinations, edited by D.M. Levinson and K.J. Krikez, 131-147. Oxford: Elsevier.

17. Hong, J., Sila-Nowicka, K. \& McArthur, D.P. (2018) Is the popularity of social networking services beneficial for public health? Focusing on active travel and BMI. Journal of Transport and Health, 11, 183-192. 
18. Hunt, J.D. \& Abraham, J.E. (2007) Influences on bicycle use. Transportation, 34, 453-470.

19. Kaplan, S., Wrzesinska, D.K. \& Prato, C.G. (2018) Psychosocial benefits and mood improvement from habitual bicycle use. $98^{\text {th }}$ Annual Meeting of the Transportation Research Board.

20. Lachapelle, U., Frank, L., Saelens, B.E., Sallis, J.F. \& Conway, T.L. (2011) Commuting by public transit and physical activity: Where you live, where you work, and how you get there. J. Phys. Act. Health, 8, S72-S78.

21. Laverty, A.A., Mindell, J.S., Webb, E.A. \& Milette, C. (2013) Active travel to work and cardiovascular risk factors in the United Kingdom. Amer. J. Prev. Med., 45, 282-288.

22. Lim, SS. Vos, T., Flaxman, AD., Danaei, G., Shibuya, K., Adair-Rohani, H., et al. (2012) A comparative risk assessment of burden of disease and injury attributable to 67 risk factors and risk factor clusters in 21 regions., 1990-2010: a systematic analysis for the Global Burden of Disease Study 2010. Lancet, 380 (9859), 2224-60.

23. MacDonald, J.M., Stokes, R.J., Cohen, D.A., Kofner, A. \& Ridgeway, G.K. (2010) The effect of light rail transit on body mass index and physical activity. Amer. J. Prev. Med., 39, 105-112.

24. McCarthy, S. \& Habib, M.A., 2018. Investigation of life satisfaction, travel, built environment and attitudes. Journal of Transport \& Health 11, 15-24.

25. Nathanail, E. \& Adamos, G. (2013) Road safety communication campaigns: Research designs and behavioral modeling". Transportation Research Part F: Traffic Psychology and Behavior, 18, 107122.

26. Office for National Statistics (2014) Commuting and personal well-being. Official Statistics, United Kingdom.

27. Panter, J., Heinen, E., Mackett, R. \& Ogilvie, D. (2016) Impact of new transport infrastructure on walking, cycling and physical activity. American Journal of Preventive Medicine, 50 (2), 45-53.

28. Pratt, M., Sarmiento, O.L., Montes, F., Ogilvie, D., Marcus, B.H. \& Perez, L.G., et al. (2012) A systematic review of the evidence for Canada's physical activity guidelines for adults. Int. J. Behav. Nutr. Phys. Act., 7.

29. Pucher, J., Buehler, R., Bassett, D.R. \& Dannenberg, A.L. (2010) Walking and cycling to health: a comparative analysis of city, state and international data. Am. J. Public Health, 100, 1986-1992.

30. Steg, L. (2005) Car use: lust and must. Instrumental, symbolic and affective motives for car use. Transp. Res. Part A: Policy Pract, 39, 147-162.

31. St-Louis, E., Manaugh, K., van Lierop, D. \& El-Geneidy, A. (2014) The happy commuter: a comparison of commuter satisfaction across modes. Transp. Res. Part F, 26, 160-170.

32. Tao, T., Wu, X., Cao, J. \& Fan, Y. (2019). Exploring the non-linear relationship between the built environment and active travel in the Twin Cities. $98^{\text {th }}$ Annual Meeting of the Transportation Research Board.

33. Vale, D.S., Saraiva, M. \& Pereira, M. (2015) Active accessibility: A review of operational measures of walking and cycling accessibility. The Journal of Transport and Land Use Vol. 9, No. 1, 209-235.

34. Van We, B., Handy, S. (2014) Do future land-use policies increase sustainable travel? In: Garling, T., Ettema, D., Friman, M. (Eds.), Handbook of Sustainable Travel. Springer Science, Dordrecht, The Netherlands, pp. 231-242.

35. Wen, L.M., Orr, N., Millett, C. \& Rissel, C. (2006) Driving to work and overweight and obesity: findings from the 2003 New South Wales Health Survey, Australia. Int J Obes (Land), 30(5), 782-6.

36. Wen, L.M. \& Rissel, C. (2008) Inverse associations between cycling to work, public transport, and overweight and obesity: Findings from a population based study in Australia. Prev. Med., 46, 29-32. 